\title{
ANALISIS STRUKTURAL OBJEKTIF DALAM NOVEL PESANTREN IMPIAN KARYA ASMA NADIA
}

\author{
Zumrotul Ilmiyah \\ MTs Negeri 2 Lamongan \\ builmy89@gmail.com \\ Telp.082337545488
}

\begin{abstract}
Abstrak: Penelitian ini dilaksanakan dengan tujuan untuk mendeskripsikan (1) aspek struktur objektif dan (2) nilai pendidikan moral dalam novel Pesantren Impian karya Asma Nadia. Sumber data penelitian adalah novel Pesantren Impian karya Asma Nadia. Teknik pengumpulan data yang digunakan adalah teknik pustaka dan teknik catat yaitu dengan cara: (1) peneliti membaca novel, (2) penulis mengidentifikasi data, (3) mencatat hasil data yang berhubungan dengan novel. Metode penelitian yang digunakan peneliti metode deskripsi. Teknik analisis yang digunakan adalah teknik analisis isi. Hasil penelitian ini menunjukan bahwa (1) tema yang terdapat dalam novel yakni tekad dan usaha seorang perempuan untuk menjadi pribadi yang lebih baik setelah menjalani masa rehabilitasi di pesantren. Tokoh utamanya adalah Gadis, Rini tokoh tambahannya yaitu Teungku Umar, Teungku Hasan, Sinta dan Santi. Latar terbagi dalam dua jenis yaitu latar tempat dan latar waktu. Plot/alur yang digunakan adalah sorot balik atau flash back. Sudut pandang yang digunakan yaitu sudut pandang orang ketiga maha tahu. (2) nilai pendidikan moral yaitu sikap hormat, berbelas kasih.dan suka menolong.
\end{abstract}

Kata kunci: Asma Nadia, Struktur, Pendidikan Moral

\begin{abstract}
The research was conducted with the aim of (1) describing the objective structure aspects, (2) describing the value of moral education in the Asma Nadia Pesantren Impian novel. The object in this study is the aspect of objective structure and the value of moral education contained in the novel Pesantren Impian by Asma Nadia. The subject of his research was Asma Nadia's Dream Dream School. The instruments in this study were the researchers themselves, note books, ballpoint pens, and relevant books that could be used as reference material. Data collection techniques used by researchers used library techniques and note-taking techniques, namely by: (1) the researcher reads novel, (2) the author identifies the data, (3) records the results of the data relating to novel. The research method used by the researcher is the description method. The analysis technique used by researchers is the content technique of content analysis authors. The results of this study indicate that (1) the theme found in Asma Nadia's Pesantren Impian novel is the determination and effort of a woman to become a better person after undergoing a rehabilitation period in a pesantren. The main character is Girl, Rini is an additional figure, Teungku Umar, Teungku Hasan, Sinta and Santi. The background is divided into two types, namely the place setting and the time setting. The plot / groove used is a backlight or flash back. The point of view used is the third person's viewpoint of omniscience. (2) the value of moral education, namely respect, compassion and helpfulness.
\end{abstract}

Keywords: Nadia Asma, Structure, Moral Education 


\section{PENDAHULUAN}

Karya sastra adalah hasil seni kreatif yang membicarakan manusia dan kehidupan dengan menggunakan bahasa sebagai medianya. Pernyataan tersebut sesuai dengan welelk dan warren (1990:3) yang mengatakan sastra adalah suatu kegiatan kreatif karya seni. Sebagai karya seni yang kreatif sastra yang membicarakan manusia dengan segala kehidupannya, karya sastra tidak hanya sebagai media untuk mengungkapkan gagasan tetapi juga menampungnya denagn memberikan kreasi keindahan.

Sastra dibangun atas unsur-unsur instrinsik dan ekstrinsik. Unsur intrinsik merupakan unsur yang membangun karya sastra dari dalam yang berupa tema, alur/plot, tokoh dan penokohan, latar/setting, serta sudut pandang. Lain halnya dengan unsur ekstrinsik yakni unsur yang berada di luar karya satra, tetapi secara tidak langsung memengaruhi bangunan sistem organisasi karya sastra, misalnya sebuah novel yang hadir di tengah pembaca merupakan sebuah totalitas.

Novel merupakan jenis karya sastra yang berjenis narasi dan berbentuk prosa. Novel terdiri dari sebuah unsur yang saling berkaitan dan secara erat membentuk satu kesatuan sebuah cerita. Salah satu penulis wanita Indonesia yang sangat produktif yakni Asma Nadia. Banyak karya yang dihasilkan di antaranya novel Pesantren Impian karya Asma Nadia yang dicetak pada tahun 2004. Novel tersebut sangat menarik untuk diteliti, karena memberikan pesan moral yang menarik yang terdapat dalam nilai-nilai pendidikan.

Novel Pesantren Impian karya Asma Nadia tahun 2014 menceritakan kisah lima belas remaja putra dan putri dengan masa lalu yang kelam yang menerima undangan misterius dari pesantren impian. Sebuah pesantren yang bisa menjadi pusat rehabilitasi bagi anakanak muda yang bermasalah dan mendapat ketenangan dengan lebih mendekatkan diri kepada sang pencipta, selain itu novel pesantren impian juga menggambarkan tekad tokoh dalam cerita untuk menjadi pribadi yang lebih baik selama menjalani rehabilitasi.

Dalam penelitian ini peneliti menggunakan pendekatan objektif atau pendekatan struktural, yakni pendekatan yang memfokuskan perhatian kepada karya sastra yang lebih menitikberatkan pada teks sastra. Teori struktural objektif yaitu teori yang semata-mata memusatkan pada unsur-unsur yang dikenal dengan analisis intrinsik. Pemahaman dipusatkan pada analisis terhadap unsur-unsur dalam dengan mempertimbangkan keterjalinan antarunsur di satu pihak, dan unsur-unsur dengan totalitas di pihak yang lain (Ratna, 2013: 73).

Alasan peneliti dalam meneliti novel Pesantren Impian karya Asma Nadia karena berisi cerita yang baik dan menarik yang turut memberikan pengaruh dan peranan dalam pembentukan watak, perilaku, dan kepribadian seseorang. Isi cerita dalam novel tersebut mampu memotivasi para pembaca agar dapat memiliki tekad dan usaha yang kuat untuk mengubah diri menjadi pribadi lebih baik seperti tokoh dalam cerita tersebut.

\section{METODE PENELITIAN}

Penelitian ini termasuk penelitian deskriptif kualitatif. Fakta atau data merupakan sumber-sumber informasi yang menjadi basis analisis (Siswantoro, 2010:57). Sumber data dalam penelitian ini adalah novel Pesantren Impian karya Asma Nadia. Instrumen yang digunakan Teknik analisis data dalam penelitian ini bersifat kualitatif. Dalam penelitian kualitatif digunakan metode content 
analysis, artinya penulis membahas dan mengkaji isi novel Pesantren Impian karya Asma Nadia

\section{Hasil Penelitian dan Pembahasan Tema}

Tema yang ditemukan dalam novel Pesantren Impian karya Asma Nadia yakni tekad dan usaha seorang perempuan untuk menjadi pribadi yang lebih baik setelah menjalani rehabilitasi di Pesantren Impian. Hal ini tergambarkan melalui tokoh Gadis.

"PI, begitu anak-anak menyebut pesantren mereka sekarang, memang berbeda. Di sini selain belajar lebih dalam tentang islam, belajar mengaji Quran dengan tajwid yang benar, para santri juga mendapat pelajaran memasak, keterampilan, bahasa arab dan inggris, bahkan kelas komputer, "

Tidak hanya kegiatan keagamaan yang diberikan oleh pesantren kepada Gadis dan remaja lainnya sebagai masa rehabilitasi, tetapi kegiatan lainnya seperti kegiatan rutin olahraga dan keterampilan lainnya.

Usaha Gadis untuk menjadi pribadi yang lebih baik dapat terealisasi dengan keinginan yang kuat selama berada di Pesantren Impian dengan bimbingan untuk menjalankan ibadah sholat dan ibadah sunah. Hal tersebut dapat dilihat dalam kutipan berikut:

\footnotetext{
"Setiap hari senin dan kamis, semua dijadwalkan berpuasa sunah. Sholat lima waktu yang biasa sering diabaikan, di PI dilakukan dengan terti dan berjamaah. Saat ada yang merasa malas, terutama sholat shubuh, entah siapa yang memulai, si pemalas akan dihujani kritikan pedas. Bayangkan, oleh empat belas pasang tangan!"
}

Kewajiban yang dulu sering ditinggalkan Gadis selama di pesantren dilakukan dengan sungguh-sungguh. Selain bimbingan untuk menjalankan ibadah sholat, motivasi untuk menjadi pribadi yang baik bisa didapat dari lingkungan sekitar atau pun dukungan teman-temannya, seperti yang dituliskan dalam kutipan tersebut" si pemalas akan dihujani kritikan habis" yang menunjukan bahwa para remaja tersebut saling membantu agar mereka dapat menjalan ibadah secara tertib.

\section{Tokoh dan Penokohan}

Dalam Novel Pesantren Impian karya Asma Nadia, menampilkan Gadis sebagai tokoh utama. Ia digambarkan sebagai perempuan pekerja keras, penyayang dan suka menolong dengan penggambaran fisik yang cantik dan memiliki tubuh yang langsing. Sifat penyayang dan suka menolong Gadis terlihat ketika ia mau mengasuh anakanak jalanan dan memberikannya tempat tinggal. Alasan ia mau mengasuh anakanak tersebut dapat dilihat dari latar belakang Gadis yang berasal dari panti asuhan. Berkaitan dengan hal tersebut, dapat dikatakan alasan ia memberikan tempat tinggal untuk anak-anak jalanan karena ia tidak ingin anak-anak tersebut merasakan hal yang serupa dengannya, hidup tanpa kasih sayang orang tuanya, dan hidup tanpa punya tempat untuk singgah. Seperti dalam kutipan berikut;

\footnotetext{
“Wanita cantik berperawakan tinggi langsing yang tampak berantakan itu, apa yang tengah dilakukannya."
}

Gadis tumbuh tanpa kenal orang tua kandungnya. Usia lima belas tahun, ia harus keluar dari panti. Mengingat tempat yang terbatas, mereka harus memprioritaskan anak-anak yang lebih kecil. Setelah itu kerja serabutan, dan tingggal berpindah-pindah. Tiga tahun kemudian mengontrak sebuah rumah yang agak besar dan membiarkannya terbuka bagi anak-anak jalanan yang ia temui."

Selain itu tokoh Gadis juga menjadi salah satu tokoh yang datang ke Pesantren Impian dengan latar belakang ia sebagai 'wanita malam'. 
Selain tokoh utama dalam cerita juga terdapat tokoh tambahan yang memiliki kadar keutamaannya tidak sama dengan tokoh utama. Tokoh-tokoh tersebut dianataranya;

\section{Rini}

Rini digambarkan sebagai tokoh perempuan yang sabar dan pantang menyerah. Rini merupakan salah satu tokoh yang datang ke Pesantren Impian. Ia datang bukan karena riwayat kejahatan yang pernah dilakukan tetapi datang sebagai korban pemerkosaan untuk menjalani masa pemulihan semangat dan percaya dirinya dengan kegiatan keagamaan yang semakin mendekatkan Rini dengan Tuhan, dan mendatangkan ketenangan dalam hatinya. Sifat sabar Rini terlihat ketika ia harus menghadapi bahawa ia menjadi korban pemerkosaan dan menghadapi permasalahan yang muncul akibat peristiwa tersebut kenyataan menjadi korban pemerkosaan, dan yang paling membuat kecewa adalah pelaku dari pemerkosaan tersebut adalah keluarganya sendiri.

"Penderitaan luar biasa. Ia sudah berusaha sabar dan mengikhlaskan semua kepada Gusti Allah. Melarutkan diri dalam sholat, doa, dan dzikir, tapi tetap tidak bisa. Belum bisa menghapus dendam di hatinya. Dia hanya korban. Kenapa justru laki-laki yang menodainya dibiarkan bebas?"

\section{Teungku Umar (Umar)}

Umar adalah pemilik Pesantren Impian, ia digambarkan sebagai pemuda yang bekerja keras. Sebelum ia membangun pesantren, ia adalah pemuda yang memiliki riwayat kejahatan dalam kasus narkotika. Hal tersebut tergambar dalam kutipan berikut;

\footnotetext{
"Usianya baru empat belas, belum cukup kuat untuk menampik godaan sedemikian rupa besar. Bersama teman-teman, mereka berdagang dan memperluas lading. Anak muda itu bekerja keras, belajar banyak dari mulai proses penanaman sampai pascapanen.
}

Ia juga memulai membaca banyak buku tentang penjualan.

Ketika waktunya tiba. Lelaki itu memutuskan membuka sendiri. Ia baru delapan belas tahun saat memiliki lading ganja terbesar di Aceh."

\section{Teungku Hasan}

Teungku Hasan digambarkan sebagai tokoh yang disegani karena ia adalah laki-laki yang suak menolong. Tengku Hasan diceritakan menjadi pemilik pesantren Impian untuk membantu menjalankan misi kebaikan Umar. Hal tersebut terlihat dalam kutipan berikut;

"Hanya satu yang dimintanya pada Tenguku Hasan, yaitu untuk berpura-pura menjadi pemilik pulau dan Pesantren Impian. Meski berat, permintaan tersebut akhirnya disetujui. Lelaki paruh baya itu bisa mengerti keinginan umar. Beliau bersedia menandatangani semua surat dan akte yang menyangkut kepemilikan tanah di pulau dan pesantren atas namanya."

\section{Butet}

Butet adalah anak muda yang diundang untuk datang ke Pesantren Impian karena riwayat kejahatannya sebagai pengedar narkoba, namun riwayat kejahatannya tersebut tidak membuat Butet menjadi seseorang yang tidak memiliki sisi kebaikan. Kutipan di bawah ini menggambarkan penokohan pada tokoh Butet.

"Rini terus menggeleng, berharap ini suatu mimpi buruk dan bukan kenyataan. Tapi saat matanya menatap surat yang masih ditangan tangis Rini makin keras."

"Rin, sabar Rin. Kau kenapa? Butet mengusap bahu rini. Mencoba menenangkan.

\section{Sinta dan Santi}

Sinta dan Santi adalah saudara kembar yang diundang untuk datang ke Pesantren Impian dengan riwayat masa lalu mereka yaitu pemakai narkoba. Latar belakang Sinta dan Santi, mereka berasal dari keluarga broken home, apabila melihat latar belakang Sinta dan Santi 
terdapat kemungkinan bahwa alasan mereka menggunakan narkoba adalah tempat pelarian masalah yang mereka hadapi. Pada penceritaan kedua tokoh ini tidak terlalu memberikan penekanan pada penokohan mereka tetapi melalui perilaku yang dilakukan oleh kedua tokoh ini dapat menyiratkan penggambaran penokohan mereka. Seperti pada kutipan di bawah ini;

"Gadis itu sadar, ia butuh bantuan. Kalau tidak bisa-bisa ia macaw lagi. Tangan kurus sinta terjulur ke arah ustadzah Hanum, menyerahkan kantong plastik kecil berisi serbuk putih, yang selama ini disembunyikan di kloset. Serbuk mimpi, putaw!"

\section{Alur/Plot}

Alur yang digunakan dalam novel Pesantren Impian merupakan plot sorot balik atau flash back karena menyoroti keadaan tokoh Gadis dan peristiwa yang dialaminya untuk mengungkapkan tokoh Gadis dengan diawali penggambaran konflik yang tengah meruncing, kemudian baru tahap awal cerita dikisahkan.

\section{Latar}

\section{Latar Tempat}

Latar tempat dalam novel Pesantren Impian berfungsi sebagai latar fungsional dan latar netral. Latar fungsional meliputi latar tempat hotel dan latar tempat pesantren Impian, sedangkan latar netral adalah latar tempat R.S Darmo Surabaya, pulau Lhok Jeumpa Aceh dan pesisir pantai.

\section{Hotel}

\section{Medan, Tiara Hotel}

"Ya Tuhan, kenapa begini?

Gadis berambut panjang itu memandang sekeliling dengan paras pucat. Di hadapannya tergeletak sesosok tubuh tak bergerak. Beling pecahan botol berserakan, berbaur dengan percikan darah yang melebar menodai karpet."

\begin{abstract}
"Bodoh! Gadis itu berulang kali menepuk kening, mestinya lelaki itu cuma pingsan, kalau saja ia tidak menghantamnya terlalu keras.

Panik perempuan muda itu membersihkan noda darah di blus putihnya. Ketika tak juga hilang, ia meraih jas si lelaki yang kebesaran, lalu tergesa melangkah ke luar kamar hotel. Sesegera mungkin dia harus menemukan tempat persembunyian yang aman. Tapi ke mana?"
\end{abstract}

\section{Pesantren Impian}

Penggambarannya dapat dilihat pada kutipan berikut;

"Dari luar pesantren, terlihat seperti kompleks bangunan segi empat sederhana dengan gerbang tinggi dan tembok yang mengelilingi area pesantren putri. Ketika gerbang dibuka, barulah tampak kemegahannya. Masjid terletak di depan, dan menjadi objek pertama yang dilihat. Di sekeliling masjid terdapat taman dengan rumput kehijauan dan bunga warna-warni.

\section{RS Darmo Surabaya}

"RS. Darmo, Surabaya.

Rini membuka mata perlahan. Dirasakan kepala teramat berat ketika ia mencoba mengingat apa yang terjadi. Ruangan putih pucat di sekitarnya jelas bukan rumah.

Pandangan yang masih samar kemudian hinggap pada seraut wajah yang teramat akrab. Wajah yang selalu ia hormati."

Kutipan tersebut menggambarakan sebuah ruangan di rumah sakit di RS. Darmo tetapi pendeskripsian ruangan di rumah sakit kurang mendetail. Kutipan tersebut menggambarakan Rini yang baru tersadar dari keadaan pingsan dari usaha bunuh dirinya setelah peristiwa pemerkosaan yang dilakuka oleh paklik kusno. Peristiwa pemerkosaan tersebut yang mendorong Rini datang ke pesantren impian untuk menjalani rehabilitasi memulihkan rasa percaya dirinya dan untuk mendatangkan ketenangan hati. 


\section{Pulau Lhok Jeumpa, Aceh}

Pulau Lhok Jeumpa, Aceh

"Sebuah senja di ujung Pulau Sumatera. Matahari telah memantulkan bayangan di pasir putih yang basah dijilati ombak."

"Mereka tiba pukul lima sore. Ketika feri merapat, tak ada mata yang tak terpesona melihat keindahan pulau. Tidak hanya kemilau pasir putih yang bercampur dengan kulit kerang kecil, tetapi juga menyaksikan jernih air laut dengan kebiruan berbeda sesuai kedalamannya."

Kutipan tersebut menggambarkan bahwa pulau Lhok Jeumpa, Aceh terletak di pulau Sumatera. Pada kutipan kedua, menunjukan kedatangan Gadis dan para remaja lainnya yang tiba di Pulau Lhok Jeumpa, Aceh karena Pesantren Impian digambarkan berada di pulau tersebut. Pasir putih yang berkemilau dan air laut yang jernih dengan warna kebiruan menandakan bahwa laut di pulau tersebut belum tercemar dengan limbah atau pun kotoran lainnya. Hal tersebut berkaitan dengan pulau Lhok Jeumpayang belum banyak didatangi oleh orang lain. Seperti yang dipaparkan oleh pengarang dalam novel, bahwa pulau Lhok Jeumpa tidak tertulis dalam peta, sehinga sulit bagi orang lain untuk menemukan lokasi pulau tersebut kecuali para penghuni Pesantren Impian.

\section{Latar Waktu}

Latar waktu dalam novel Pesantren Impian terdapat dua latar waktu yakni latar waktu tahun 1979 dan tahun 2003.

\section{Tahun1979}

“Aceh 1979

Kelahirannya disambut gembira. Aqiqohan diadakah secara besar-besaran. Ayah memilih dua ekor kambing terbaiknya untuk disembelih, sebagai rasa syukur. Kehadiran anak lelaki adalah yang paling dinantinya. Empat anak yang dilahirkan Maimon sebelumnya perempuan. Seisi desa turut gembira dengan kehadiran bungsu keluarga Teungku Muhammad Ramli.
Ayah menamainya Umar (....)."

Kutipan tersebut menggambarkan latar waktu kelahiran umar, seorang lakilaki yang menjadi pemilik Pesantren Impian. Teungku Muhammad Rafli memberikan nama Umar kepada putranya karena ia kagum dengan pahlwan Aceh yang melegenda yaitu Teungku Umar, ia berharap kelak semangat pahlawan tersebut dapat tertanam dalam diri Umar.

\section{Tahun 2003}

"Pulau Lhok Jeumpa, 2003

Teungku budiman memandang bangunan setengah jadi dihadapannya. Di sebelah laki-laki itu berdiri pengacara sekaligus orang kepercayaan yang sangat berperan dalam proyek ini.

Memang belum selesai, pikirnya. Tapi seolah sudah terbayang seperti apa bangunan ini setelah jadi nanti. Lelaki itu memejamkan mata. Satu bangunan megah yang komplit pun terlukis."

Kutipan tersebut menunjukan pembangunan pesantren yang bertujuan untuk membantu para membantu para anak muda yang memiliki riwayat kejahatan ataupun bagi mereka yang memiliki permasalahan dalam hidupnya untuk mendapatkan ketenangan. Kenyamanan merupakan upaya pertama untuk membuat mereka merasa tenang, tanpa itu mustahil mereka bisa menjalani rehabilitasi dengan baik.

\section{Pagi hari}

"Selepas subuh, mereka, kecuali Rini, berkumpul di lantai tiga, ruang olahraga."

"Perpisahan bagi si gadis terjadi lebih dini, pagi-pagi sekali ba'da sholat Subuh, ia menyampaikan kepulangan yang dipercepat.

Pada kutipan pertama menunjukan aktivitas rutin yang dilakukan para remaja selama berada di pesantren, setelah sholat Subuh mereka memang dibiasakan untuk berolahraga di pagi hari yang bertujuan untuk berolahraga di pagi hari yang bertujuan untuk menjaga kebugaran tubuh mereka selama 
menjalani rehabilitasi dan untuk mengalihkan perhatian mereka dari perilaku-perilaku buruk yang pernah mereka lakukan. Setelah olahraga para remaja tersebut mengisi waktu mereka dengan pelajaran keterampilan yang telah disediakan pesantren.

\section{Sore hari}

"Mereka tiba pukul lima sore, semua berjumlah tiga puluh orang, ditambah empat pemimpin rombongan. (...)",

Kutipan tersebut menggambarkan kedatangan para remaja di Pulau Lhok Jeumpa, Aceh. Perjalanan dengan jarak tempuh yang jauh dengan menggunakan kapal feri membuat mereka tiba di Pulau Lhok Jeumpa pada sore hari, selain itu kondisi laut mempengaruhi waktu lamanya perjalanan mereka.

\section{Malam hari}

"Ketika malam tiba, keputusan si Gadis sudah bulat. Ia akan minta izin pesantren untuk diperbolehkan pulang lebih cepat. Bocah-bocah tersayang membutuhkan kehadirannya."

Kutipan tersebut menunjuk pada tokoh gadis, kutipan ini berkaitan dengan kutipan yang terdapat di latar waktu pagi hari. Keputusan gadis untuk pulang lebih awal karena ia menerima surat dari seseorang yang dipercayainya untuk menjaga anak-anak asuhnya selama ia pergi ke pesantren impian. Gadis khawatir dengan anak-anak asuhya karena dalam surat diberitahukan bahwa anak-anak sudah mulai kelaparan karena mereka tidak mempunyai uang untuk membeli makanan oleh karena itu Gadis berniat pulang lebih awal.

\section{Sudut Pandang}

Sudut pandang adalah cara atau pandangan pengarang sebagai sarana menyajikan tokoh, tindakan, latar dan berbagai peristiwa yang membentuk cerita. Seperti dalam kutipan di bawah ini;

"Hanya si Gadis yang dengan saksama memerhatikan raut muka dan menangkap keresahan dan genangan air mata di sana. Pasti ada yang tak disangka, bati si Gadis. Diam-diam ia meninggalkan kerumunan.”

"Situasi semakin tak terkendali ketika kemudian tubuh gendut menubruk dan mekasanya ke tempat tidur. Si Gadis berusaha meronta dan menendang sia-sia.

Pada kutipan tersebut yang bercerita adalah orang yang tidak terlibat dalam cerita. Melalui penggambaran yang dilakukan pengarang dengan sudut pandang orang ketiga maha tahu, pencerita pada dasarnya ingin menggambarkan peristiwa fisik maupun peristiwa yang terjadi dalam perasaan tokoh, selain itu sut pandang orang ketiga maha tahu mempermudah pembaca dalam melihat pesan yang ingin disampaikan oleh pengarang.

\section{Pendidikan Nilai Moral}

Nilai-nilai moral yang tampak pada novel pesantren Impian Karya Asma Nadia terlihat pada cerita, dialog, peristiwa, ataupun penokohan dalam cerita. Nilai-nilai moral tersebut dirangkum menjadi sikap hormat, berbelas kasih dan suka menolong.

\section{Sikap hormat}

Sikap hormat menunjukan penghormatan dan bakti melalui sikap yang baik dari sudut pandang tata bahasa maupun tata perilaku, hal tersebut dapat dilihat dalam kutipan berikut;

"Tapi demi ibu, ia harus menyapa sanak keluarga dan mereka telah meluangkan waktu menjenguk. Demi ibu, sakit atau tidak, ia tidak boleh kehilngan tata karma."

"Sebenarnya ia masih bisa bersikeras menolak, Cuma lagi-lagi tak sanggup membantah tatapan ibu. Dalam banyak hal rasanya lebih nyaman jika tidak bertentangan 
dengan wanita yang melahirkannnya. Lagi pula ia tidak ingin lebih mengecewakan ibu."

Kedua kutipan tersebut menggambarkan sikap hormat Rini kepada ibunya. Rini menyadari bahawa ibunya adalah seorang perempuan yang sangat menjaga nama baik keluarganya dihadapan orang lain. Berdasarkan kutipan tersebut, sikap yang ditunjukan rini kepada ibunya merupakan penggambaran sikap bakti seorang anak kepada orangtuanya.

Pesan moral yang disampaikan dalam hal ini adalah kebaikan kepada orang tua dan mengajarkan untuk tidak menunjukan sikap yang dapat menyakiti orang tua.

\section{Berbelas kasih}

Berbelas kasih adalah ikut merasakan keadaan yang tengah dialamin orang lain. Berbelas kasih merupakan sisi empati karena peduli dengan keadaan orang lain. Seperti dalam kutipan berikut.

\footnotetext{
"Rin, jangan sedih gitu dong. Nanti aku jadi ikut sedih, nih!” Butet mengusap matanya yang mulai berair. Gadis Medan ini sensitif juga rupanya."
}

\section{Suka Menolong}

Sikap suka menolong adalah keikhlasan dalam membantu sesama. Sikap suka menolong dalam cerita ini tidak hanya tergambarkan melalui sikap para tokoh.

\footnotetext{
"Belakangan lelaki itu menawarkan keinginannya membeli seluruh tanah di pulau dari penduduk asli. Tidak ada yang keberatan, tidak juga dari kalangan ulama, karena
}

Teungku Budiman, begitu mereka biasa menyebutnya, sudah berbuat banyak. Apalagi dalam kontrak jual beli disebutkan bahwa penduduk bisa tetap tinggal, bahkan bekerja di perkebunan milik Teungku."

\section{SIMPULAN}

Berdasarkan hasil analisis nilai moral tersebut menggambarkan nilai moral, yaitu sikap hormat, sikap berbelas kasih, dan sikap suka menolong. Hal tersebut memiliki kaitan dengan amanat dalam novel ini yaitu pada hakikatnya manusia memiliki kebaikan dalam dirinya. Kebaikan tersebut berupa sikap suka menolong dan tekad untuk menjadi pribadi seperti yang tergambarkan melalui penokohan pada tokoh utama yaitu Gadis, tetapi penggambaran nilaimoral tidak hanya terdapat pada tokoh utama tetapi juga terlihat pada tokoh tambahan lainnya. Berdasarkan hal tersebut dapat disimpulkan bahwa semua tokoh dibangun dengan misi menuju kebaikan yang dikenal sebagai tokoh stereotip.

\section{DAFTAR PUSTAKA}

Luxemburg, dkk. 1992. Pengantar Ilmu Sastra terj. Dick Hartoko. Jakarta: Gramedia Pustaka Utama.

Nurgiyantoro, Burhan. 1995. Teori Pengkajian Fiksi. Yogyakarta: GajahMada University Press.

Ratna, Nyoman Kutha. 2013. Teori, Metode, dan Teknik Penelitian Sastra. Yogyakarta: Pustaka Pelajar. 